\title{
HISTOPATHOLOGICAL, HISTOCHEMICAL AND PHYSIOLOGICAL STUDIES ON THE EFFECT OF THE INSECTICIDE "HOSTATHION" ON THE LIVER OF THE CATFISH CLARLAS gariepinus
}

\author{
Saber A. Sakr ${ }^{1}$ Soad M. Hanafy ${ }^{2}$ and Nabila I. El-Dosouky ${ }^{3}$ \\ 1-Zoology Department, Faculty of Science, Menufiya University, egypt \\ 2-Zoology Department, Faculty of Science, South Valley University, egypt \\ 3-Zoology Department, Faculty of Science, Tanta University, egypt
}

Key words: Pollution, catfish, liver, histopathology, histochemistry, physiology.

\begin{abstract}
$\mathrm{T}^{\mathrm{n}}$ the present work experiments were carried out to investigate the 1 hazardous effects of the organophosphorous insecticide (Hostathion) on the histology, histochemistry and physiology of the liver of the catfish (Clarias gariepinus) after exposure to $\mathrm{LC}_{50}$, $1 / 2 \mathrm{LC}_{50}$ and $1 / 4 \mathrm{LC}_{50}$ of the insecticide for different periods. The results showed that the histopathological changes induced in the liver were mainly represented by liver cord disarray, cytoplasmic vacuolization of the bepatocytes, damage of blood sinusoids, blood vesse] congestion and inflammatory leucocytic infiltration. The histochemical observation revealed marked reduction in glycogen contents and total protein contents of the liver cells as compared with the control material. Physiologically, different treatments at different time intervals resulted in variable degrees of inhibition in $5^{\prime}$ nucleotidase and alkaline phosphatase activities. These changes were both concentration- and time- dependent.
\end{abstract}

\section{INTRODUCTION}

Pesticides have been widely used all over the world for several decades to eliminate pests. Random and indiscriminate use of pesticides have been continuously creating serious problems to aquaenvironment since these pesticides usually find their way to the aquatic ecosystem through various routes (Caldas et al., 1999 and Hassanein, 1999). Therefore, it is necessary to study in detail the possible impacts of these hazardous chemicals on the aquatic 
organisms with special emphasis on the most economic ones, viz, the fishes. Such pesticides are also known to have affinity for residing in animal tissues, especially in the fatty ones( Deichmann et al.1975).

There is considerable information indicating that pesticides are responsible for many adverse impacts in fishes and other animals from the histopathological, histochemical and physiological points of view (Bansal et al., 1979; Verma et al., 1983; Sastry and Siddique, 1984; Abdel-Aziz, 1985; Hassanein, 1991; Soliman et al., 1993; Elezabi et al., 2001).

In Aswan governorate, which represents the local area of the present investigation, thousands of tons of insecticides, especially organophosphorous compounds, are dumped and used for eradication of insects around the shore of High Dam lake as such area can be a passway to the invasion of dangerous insects to Egypt from the Sudan. Of these insects, is the mosquitos, Anopheles gambiae, which carries the causative agent Falciparum malaria. For eradication of these dangerous insects the Malaria station in such areas uses all types of insecticidal protection at all possible modes of application in terms of using dusting powder, solutions, emulsions and water suspensions. These insecticides find their way directly to High Dam lake causing water pollution which became a great hazard for aquatic life. This hazardous problem attracted the attention of a number of investigator to initiate a serics of investigations. In the present investigation, the organophosphorous insecticide hostathion was chosen to study its effects on histological, histochemical and physiological aspects of the liver of one of the economic fresh water fish namely the catfish "Clarias gariepinus".

\section{MATERIALS AND METHODS}

\section{Experimental animals:}

Living samples of Clarias gariepinus were collected from the High Dam Lake, each weighing 500-750 g. The fish samples were transported in well-aerated containers to large tanks in the laboratory. These tanks contain Nile water and were continuously aerated using air pumps. The fish samples were kept for at least 24 hours in these tanks before experimentation. The fishes were provided with suitable food of algae and grass. 
EFFECT OF THE INSECTICIDE "HOSTATHION" ON 105 THE LIVER OF CLARLAS GARIEPINUS

\section{Tested pollutant:}

An organophosphrous insecticide was used in the present study, namely Hostathion. This insecticide is widely used for eradication of gambian mosquitoes at the region of High Dam Lake. Its active ingredient in the commercial compound was $40 \%$. Dilutions of different concentration were prepared by emulsification with water.

\section{Determination of $\mathrm{LC}_{50}$ :}

The concentration of hostathion which causes $50 \%$ live-death response $\left(\mathrm{LC}_{50}\right)$ at 96 hours was determined. Groups of 10 fishes were exposed to gradual concentrations (Table 1) of the insecticide for 96 hours. $\mathrm{LC}_{50}$ value was obtained by plotting the percentage of mortality versus concentration on semi-log paper (Fig. 1).

\section{Experimental design:}

The experimental fishes were divided into four groups.

The $1^{\text {st }}$ group: 25 fishes were exposed to $\mathrm{LC}_{50}(3 \mathrm{mg} / \mathrm{l})$ of hostathion for 24 hours exposure period in specially equipped aquaria $(80 \times 50 \times 50 \mathrm{~cm})$. During this period, the fishes that die were immediately removed. On the other hand, the surviving individuals were decapitated after the intervals of 6,12 and 24 hours post exposure.

The $2^{\text {nd }}$ group: 25 fishes were exposed to acute treatment $\left(1 / 2 \mathrm{LC}_{50}\right)$ of hostathion. This concentration was prepared by emulsifying $1.5 \mathrm{mg} / 1$ in the Nile water. Fishes were kept under observation for 4 days exposure period and sampled after 2,3,4 days post exposure.

The $3^{\text {rd }}$ group: 25 fishes were exposed to chronic treatment $\left(1 / 4 L_{50}\right)$ $(0.75 \mathrm{mg} / 1)$. The experiment continued for 15 days and sampled after 5,10 and 15 days from the beginning of exposure.

The $4^{\text {th }}$ group: 10 fishes were used as a control and kept in Nile water without any treatment.

At the end of each exposure time, fishes were decapitated and the liver was taken for determination of different investigations.

\section{Histological and histochemical investigations:}

Immediately after decapitation, the fishes were dissected and small pieces of the liver were fixed in $10 \%$ formalin and Carnoy's fluid. The fixed samples were dehydrated in ascending series of 
ethanol, cleared in methyl benzoate and embedded in paraffin wax. Sections of 5-7 $\mu \mathrm{m}$ thickness were cut, mounted and stained with different stains according to the target of investigation. For histopathological investigations, $10 \%$ formalin - fixed sections were stained with haematoxylin and eosin. For histochemical investigations, materials fixed in Carnoy's fluid were stained with periodic acid Schiff's (PAS) technique (Hotchkiss, 1948) for demonstration of polysaccharides (liver glycogen). Total proteins were demonstrated by the mercury bromophenol blue method (Mazia et al., 1953).

\section{Physiological investigation}

Immediately after decapitation, the liver was removed, washed, homogenized and kept in deep freezer at $-20^{\circ} \mathrm{C}$ until used. 5 -Nucleotidase assay was performed using the method of El-Aaser and El-Merzabani (1975).The principle of this method depends on the incubation of the specific substrate adenosin-5-monophosphate with the enzyme at $\mathrm{pH} 7.5$ and determination of the liberated inorganic phosphorous. The formed colour is estimated at wave length $640-720 \mathrm{~nm}$. Alkaline phosphatase activity was estimated using the method of Kind and King (1954). The method is based on the hydrolysis of disodium phenyl phosphate with the liberation of phenol and formation of disodium phosphate. In the presence of alkaline oxidizing agents 4-amino-phenazone, 4-amino-antipyrine, a red or purple colour is formed with compounds containing a phenolic group. The amount of the formed phenol is estimsted colourimetrically at wave length $520 \mathrm{~nm}$.

\section{RESULTS}

\section{Histopathological results:}

In liver sections of normal fish the hepatocytes form a rather cord-like pattern (Fig. 2). These cords are arranged around tributaries of the hepatic vein. The liver cells are large in size, polygonal in shape with homogenous eosinophilic cytoplasm and centrally located nuclei. A large number of blood sinusoids were also observed.

Haematoxylin and eosin stained sections of the fish liver have displayed pathological changes after treatment with different concentrations of the applied insecticide. 


\section{EFFECT OF THE INSECTICIDE "HOSTATHION" ON 107 THE LIVER OF CLARLAS GARIEPINUS}

\section{Effect of $\mathbf{L C}_{50}$ :}

Exposure of Clarias gariepinus to $\operatorname{LC}_{50}(3 \mathrm{mg} / 1)$ of hostathion for 6 hours had induced obvious histopathological changes in the liver. These changes included marked pathological changes of hepatic cells, inflammatory leucocytic infiltrations and congestion of the intrahepatic blood vessels (Fig. 3). After 12 hours, the hepatocytes have lost their normal architeture and a large number of these cells appeared with pyknotic nuclei. The sinusoidal lumina were constricted and congested with blood cells (Fig. 4). The histopathological changes of the liver were more pronounced after 24 hours; the liver cells were degenerated and suffered from cytoplasmic vacuolization (Fig. 5). The intrahepatic blood vessels were dilated and congested.

\section{Effect of $1 / 2 \mathbf{L C}_{50}$}

Treatment of fishes with this concentration for 2 days induced remarkable pathological changes. The hepatocytes lost their cord-like arrangement and the tissue displayed some necrotic areas (Fig. 6). Marked congestion of blood vessels was observed after 3 days of treatment (Fig. 7) and the lumens of hepatic sinusoids were narrowed. Later on, after 4 days, clear degeneration of hepatocytes was detected; the cells exhibited large number of cytoplasmic vacuoles and pyknosis of nuclei. The blood sinusoids could not be seen as they suffered great narrowing (Fig. 8).

\section{Effect of $1 / 4 \mathrm{LC}_{50}$}

Treatment of fishes with this concentration of hostathion for five days had caused disarray of hepatic cords, the blood sinusoids appeared containing degenerated blood cells. The toxic change was more sever after 10 days of exposure to this concentration, the tissue showed marked inflammatory leucocytic infiltrations and congestion of blood vessels (Fig. 9). The histopathological pathological lesions observed at the end of treatment (15 days) can be summarized as follows: the hepatocytes appeared enlarged and their nuclei suffered from karyolysis (Fig. 10). Some specimens showed hepatocytes with severe cytoplasmic vacuolization and a large number of binucleated cells were observed (Fig. 11). The blood sinusoids became so narrow that they almost became obscure (Fig. 11). 
Histochemical results:

\section{Glycogen content}

In normal liver of Clarias gariepinus, large amounts of glycogen were observed in the cytoplasm of the hepatocytes as indicated by large number of reddish fine granules of different sizes (Fig. 12a).

After exposure of fishes to $\mathrm{LC}_{50}(3 \mathrm{mg} / 1)$ of hostathion for 6 hours, glycogen content of the liver cells decreased (Fig. 12b). This diminution of glycogen inclusions became more pronounced after 12 hours of treatment. Later on and after 24 hour of treatment, glycogen loss was more prominent in the hepatic tissue. This diminution was quite evidenced in the amount and stainability as represented in Fig. 12c. After treatment with $1 / 2 \mathrm{LC}_{50}$ for two days, the liver tissues showed a highly decrease in its glycogen content in the cytoplasm of most of the hepatocytes (Fig. 12d). The above feature became more marked after 3 and 4 clays in both quantity and stainability (Fig. 12e). A marked reduction of glycogen contents was noticed in different hepatocytes as noticed after 5 days of exposure to $1 / 4 \mathrm{LC}_{50}$. Most of these hepatocytes embodied large vacuoles in their cytoplasm and glycogen inclusions were confined to the intervacuolar areas. The reduction of glycogen inclusions became more marked after 10 days of treatments. This diminution was more evidenced in both amount and stainability of these substance located in between the extensive cytoplasmic vacuoles (Fig. 12f). At the end of exposure period (after 15 days), glycogen content displayed faint stainability and became hardly detectable.

\section{Total proteins}

In the hepatocytes of normal Clarias gariepinus, total proteins appeared as intensely dark blue coloured inclusions in the cytoplasm. Chromatin bodies and nucleoli exhibited a deep colouration with bromophenol blue (Fig. 13a).

Total proteins were found to exhibit a slight decrease in cytoplasm and nucleus of the liver cells of Clarias gariepinus treated with $\mathrm{LC}_{50}(3 \mathrm{mg} / \mathrm{l})$ of hostathion after lapse of 6 hours as designated in (Fig. 13b). After 24 hours of treatment, such decrease was more pronounced in the hepatocytes which appeared vacuolated (Fig. 13c). A higher decrease in protein content was detected in both the amount and stainability after exposing the experimental fishes to $1 / 2 \mathrm{LC}_{50}$ followed by examination after lapse of 2 days (Fig. 13d). This decrease of proteinic inclusion was found to be more striking in both 


\section{EFFECT OF THE INSECTICIDE "HOSTATHION" ON 109 THE LIVER OF CLARIAS GARIEPINUS}

the relative amount and intensity in the hepatocytes examined After treatment $\left(1 / 4 \mathrm{LC}_{50}\right)$ with hostathion, considerable decrease of proteinic materials was observed in the liver. After 15 days, there was an obvious reduction in the protein contents and their remnants were mainly located at the peripheries of the hepatic cells which showed sever cytoplasmic vacuolation (Fig. 13f).

\section{Physiological results:}

5 '-nucleotidase

Treatment of Clarias gariepinus with the $\mathrm{LC}_{50}$ of hostathion for 24 hour had induced a highly significant $(\mathrm{P}<0.01)$ reduction in the activity of 5 -nucleotidase. The enzyme activity was reduced by $68.76 \%, 72.88 \%$ and $77.47 \%$ after 6,12 and 24 hours of treatment, respectively. Exposing fish to $1 / 2 \mathrm{LC}_{50}$ of hostathion induced a great inhibition in the $5^{\prime}$-nucleotidase enzyme activity in the liver. The percentages of the inhibition were $72.53 \%, 74.04 \%$ and $78.36 \%$ after $2,3,4$ days post treatment, respectively. These inhibitions were found to be highly significant $(\mathrm{P}<0.01)$. Chronic treatment of fishes with $\left(1 / 4 \mathrm{LC}_{50}\right)$ of the insecticide had induced marked and highly significant $(P<0.01)$ inhibition in the activity of $5^{\prime}$-nucleotidase in the liver. The percentage of this inhibition recorded its highest value $(81.87 \%)$ after 5 days post-exposure, then its decline was $78.04 \%$ and $74.76 \%$ after 10 and 15 days respectively (Table 2 ).

\section{Alkaline phosphatase}

Fishes exposed to $\mathrm{LC}_{50}$ of hostathion showed that the activity of alkaline phosphatase in the liver was subjected to significant ( $\mathrm{p}<$ 0.05 ) inhibition after 12 and 24 hours of treatment. A marked inhibition of this enzyme was recorded after treatment with $1 / 2 \mathrm{LC}_{50}$. The inhibition percentages were $66.92 \%, 69.45 \%$ and $71.91 \%$ after 2 , 3 and 4 days respectively. All these inhibitions were highty significant $(\mathrm{P}<0.01)$. A highly significant $(\mathrm{P}<0.01)$ reduction in the alkaline phosphatase activity was recorded after treatment with $1 / 4$ $\mathrm{LC}_{50}$ of hostathion. The percentage of this reduction were $65.80 \%$ after the first 5 days and increased through 10 days of the experiment $(71.54 \%)$ where it reached its highest value (74.71\%) after 15 days of treatment (Table 2). 


\section{DISCUSSION}

Numerous organophosphorous insecticides are widely used in many parts of Egypt to control insects, pests and disease vectors. Many of the treated areas contain freshwater resources like streams, lakes and ponds which harbour diverse aquatic fauna and flora. In the present investigation a study was carried out on the effect of the organophosphorous insecticide "hostathion" on the Nile fish Clarias gariepinus. This organophosphorous compound is dumped near and around the shores of High Dam Lake to eradicate the Gambia mosquito.

It was found that hostathion induced marked histopathologiocal changes in the liver of catfish at different intervals and treatment with three concentrations i.e., $\mathrm{LC}_{50} 1 / 2 \mathrm{LC}_{50}$ and $1 / 4 \mathrm{LC}_{50}$.

It is well known that the liver is the first target organ in toxicological prospects regarding its role in detoxification, biotransformation and excretion of xenobiotics After enteric uptake of injurious materials, it is the first organ to be exposed to such hazards via the portal circulation (Wester, 1988).

In the present surdy, examination of liver sections obtained from fishes exposed to different concentrations of hostathion has shown marked histopathological lesions. These lesions included disarray of hepatic cords, cytoplasmic vacuolization of the hepatic cells, nuclear pyknosis, inflammatory leucocytic infiltrations and congestion of blood vessels.

Such lesions were previously observed by many investigators in the liver of different fish species under the effects of different types of insecticides. Eller (1971) found that there were cellular changes in the liver of Salmo clarki following food or water exposure to $0.01 \mathrm{mg}$ $/ \mathrm{kg} \mathrm{b.w.} \mathrm{or} 0.01 \mathrm{ppm}$ of the insecticide endrin. Malathion was found to induce histopathological lesions in the liver of Channa panctatus (Dubale and Shah, 1979). Mandal and Kulshrestha (1980) studied the effects of sublethal concentration of sumithion on liver, kidneys and intestine of Clarias batachys. They observed liver necrosis, vacuolization and breakdown of the cell boundaries. They also observed vacuolization of epithelial cell of uriniferous tubules and degeneration of the glomeruli in the kidney, while in the intestine, they noticed lesion formation in the villi and enlargement of mucous cells. Histological changes in the liver of Tilapia mossambica after exposure to the organophosphate monocrotophos were reported by Desai et al., (1984). At the initial stage of intoxication, necrosis and 


\section{EFFECT OF THE INSECTICIDE "HOSTATHION" ON 111 THE LIVER OF CLARIAS GARIEPINUS}

vacuolization of hepatocytes were recorded, while fatty degeneration was observed later on. Treatment with endrin produced acute pathological changes in the liver of Channa punctatus (Sastry and Sharma, 1979).

Hassanein $(1991,1999)$ reported that exposure of Gambusia affinis or Nile Bolti Oreochromis niloticus to different concentrations of malathion or goal has resulted in liver cord disarray, necrosis, cytoplasmic vacuolization of hepatic cells and disintegration of blood materials. These lesions were both concentration and time dependent. Similar findings were aiso presented by Soliman et al., (1993) in Gambusia affinis exposed to acute and chronic concentrations of malathion. Elezabi et al. (2001) studied the effect of malthion on the fish Oreochromis niloticus and their results showed that this insecticide induced many histopathological changes in the liver and gills of the fishes. These changes were hemorrhage, necrosis and destruction of lamellae of the lungs, and necrosis and lipidosis in the liver.

It was found that different concentrations of hostathion induced gradual and marked reduction in glycogen content in the hepatocytes. These results are in full agreement with those achieved by some authors who have investigated the effects of different pesticides on fishes.

In this concern, Singh and Srivastava (1981) mentioned that carbohydrates decreased as a result of exposure to a sublethal concentration of a mixture of aldrin and formothion. These insecticides had induced marked diminution in the glycogen content of the liver and muscles of this fish. Exposure of freshwater fish Mystus vittatus to sublethal concentrations of the two pesticides thiotox and dichloruos for one month was found to induce marked depletion in both liver and muscle glycogen (Verma et al., 1983). Sublethal concentrations of quinalphos resulted in reduction of glycogen in the liver of Channa punctatus (Sastry and Siddique, 1984). Shalaby (1985) remarked that carbohydrate contents in the intestinal mucosal cells of the catfish Clarias gariepinus were subjected to marked changes after exposure to a sublethal concentration of the insecticide cyolane. The author suggested that carbohydrate depletion might be due to the disturbed role of the Golgi apparatus in polysaccharide synthesis under the insecticide stress, which in turn, pushes the fish to utilize their reserve glycogen for energy needs. 
Total protein contents of the liver of Clarias gariepinus showed a noticeable decrease after treatment with hostathion. These results agree with those of Hassanein $(1991,1999)$ and Soliman et al. (1994) who reported that treatment of fishes with malathion had induced a highly significant decrease of protein contents of the liver, testis and ovary. Hepatic total protein content significantly decreased after treating freshwater fish Labeo rohita with chlordane (Bansal $e t$ al. 1979). Sancho et al. (1998) reported that total proteins had decreased in liver of the European eel, Anguilla anguilla after fenitrothin exposure for different time intervals up to $96 \mathrm{hrs}$. Hagazi et al. (1988) investigated the effect of dursban on RNA and proteins in white muscles of Clarias gariepinus. Their results proved that RNA and proteins significantly decreased and the authors attributed such decrease to an increase in the rate of protein catabolism in the muscle for energy maintenance.

The data of the present investigation reflect marked reduction in the activity of $5^{\prime}$-Nucleotidase in the liver of Clarias gariepinus after exposure to different concentrations of hostathione. 5'Nucleotidase is a specific phosphatase enzyme acting on both pyrimidine and purine nucleotides with a phosphate group attached to the fifth carbon atom of the pentose ring (Sherlok, 1981).

The present results are in agreement with the results of Abdel-Aziz (1985) who studied the effect of dimethoate, malathion and hostathion on the freshwater fish Oreachromis niloticus and found that the three insecticides had caused a significant reduction in the enzyme activity. The author marked that malathion was the most potent toxicant and reported no complete recovery in the enzyme activity after discontinuation of exposure of fishes to sublethal concentration for 24 hours. Also, Hassanein $(1991,1999)$ recorded a highly significant inhibition of $5^{\prime}$-nucleotidase activity in the liver,testis and ovary of fresh waterfish Gambusia affinis and the liver and kidneys in the Oreachromis niloticus after both acute and chronic exposure to the malathion and goal. There was no complete recovery in the enzyme activity after exposure of the fishes to fresh nontoxicated water for 15 days. It seems that the reduction in the 5 nucleotidase activity in some tissue might affect the synthesis of mucleic acid, and is ascribed to the unavailability of specific nitrogen bases necessary for the biosynthesis processes (Abdel-Aziz, 1985).

Data obtained in the present study revealcd marked inhibition of the activity of alkaline phosphatase in the liver of Clarias gariepinus after different treatments with hostathion. This is 


\section{EFFECT OF THE INSECTICIDE "HOSTATHION" ON 113 THE LIVER OF CLARIAS GARIEPINUS}

presumably attributed to the fact that the liver is the first target organ of detoxification of such hazardous compounds. This result is in agreement with that of many authors who have investigated the impacts of different pesticides on fishes. In this regard, Vcrma $e$ al (1983) observed marked reduction in the activity of alkaline phosphatase in the liver, kidneys and gills of Mystus vittatus after exposure to sublethal concentrations of the three pesticides, thiotox, dichlorouos and carbofuran. Also, Hassanein (1999) reported inhibition of alkaline phosphatase in the liver of $O$. niloticus after treatment with different concentration of goal and attributed this reduction to a decrease in the transphosphorylation activity in the liver, which in turn indicates a disturbance in liver functions.

In conclusion, the present study showed that hostathion affected the structure and functions of the liver of Clarias gariepinus and this effect was concentration- and time-dependent.

\section{REFERENCES}

Abdel-Aziz, M. B. (1985). Biochemical and physiological studies on the effect of some insecticides on the fresh water fish Tilapia nilotica from High Dam Lake. (Aswan), M.Sc. Thesis, Fac. Sci., Assiut Univ.

Bansal, S. K.; Verma, S. R.; Gupta, A. K. and Dalela, R. C. (1979). Physiological dysfunction of the haemopoietic system in a fresh water teleost Labeo rohita following chronic chlordane exposure. Part II. Alterations in certain organic components and serum electrolytes. Bull. Environm. Contam. Toxicol., 22: 674-680

Desai, A. K.; Joshi, U. M. and Ambadka, P. M. (1984). Histological observations on the liver of Tilapia mossambica after exposure to monocrotophos, an organophosphorus insecticide. Toxicol. Lett., 21:325-331.

Dubale, M. S. and Shah, P. (1979). Histological lesions induced by malathion in the liver of Channa punctatus Ind. J. Exp. Biol., 17: 693-697. 
El-Aaser, A. A. and El-Merzabani, M. M. (1975). Simultaneous determination of $5^{\prime}$-nucleotidase and alkaline phosphatase activities in serum E. Klin. Biochem., 1379: 459-563.

Elezaby, M. M.; El-Serafy, S.; Heckmann, R.; Sharf Eldeen, Kh. and Seddek, M. M. (2001). Effect of some toxicants on the fresh water fish Oreochromis niloticus. J. Egypt. Ger. Soc. Zool., 36: 407-434.

Eller, L. L. (1971). Histopathological lesions in cut throut trout Salmo clorki exposed chronically to the insecticide endrin. Amer. J. Pathol., 64: 321.

Hagazi, M. A.; Mansour, M. A. and Abdel-Ghaffar, K. M. (1988). Effect of chronic dursban intoxication on growth rate and macromolecular components (RNA, DNA and Protein) of Juvenile catfish Clarias lazera. Delta J. Sci., 12: 1724-1743.

Hassanein, H. M. A. (1991). Biological studies on the effect of some water pollutants (pesticides) on fresh water fish, Gambusia affinis. M. Sc. Thesis, Fac. Sci. (Sohag) Assiut Univ. Egypt.

Hassanein, H. M. A. (1999). Histopathological, histochemical and physiological studies on the effect of environmental pollution with the herbicide "Goal" on the liver and kidney of the Nile Bolti "Oreochromis niloticus" in Sohag governorate. Ph.D. Thesis, Fac. Sci. (Sohag) Assiut Univ.

Hotchkiss, R. D. (1948). A microchemical reaction resulting in the staining of polysaccharide structures in fixed tissue preparations. Arch. Biochem., 16: 131.

Kind, P. R. N. and king, E. G. (1954). Estimation of plasma phosphatase by determination of hydrolysed phenol with aminoantipyrine, J. Clin.'Path., 7: 322-329.

Mandel, P. K. and Kulshrestha, A. K. (1980). Histopathological changes induced by the sublethal sumithion in Clarias batrachus (Linn). Ind. J. Exp. Biol., 18: 547-552. 
EFFECT OF THE INSECTICIDE "HOST ATHION" ON 115 THE LIVER OF CLARIAS GARIEPINUS

Mazia, D.; Brewer, P. A. and Alfert, M. (1953). The cytochemical staining and measurement of protein with mercuric bromophenol blue. J. Biol. Bull., 104: 57-67.

Sancho, E.; Ferrando, M. D.; Fernandez, C. and Andreu, E. (1998). Liver energy metabolism of Anguilla anguilla after exposure to fenitrothion. Ecotoxicol. Environm. Saf., $41(2)$ : $168-175$.

Sastry, K. V. and Sharma, S. K. (1979). The effect of endrin on the histopathological changes in the liver of Channa punctatus. Bull. Environ. Contam. Toxicol., 20(5): 674-677.

Sastry, K. V. and Siddique, A. A. (1984). Some hematological, biochemical and enzymological parameters of a fresh water teleost fish Channa punctatus exposed to sublethal concentrations of quinalphos pesticide. Bioch. Physiol., 22: 8-13.

Shalaby, A. A. (1985). Effect of cyolane on the cytology and histochemistry of the ileum of Clarias lazera. M.Sc. Thesis, Faculty of Science, Zagazig Univ.

Sherlok, S. (1981). Diseases of the liver and bilary system. The $6^{\text {ed }}$ Blackwell Sci. Publications.

Singh, N. N. and Srivastava, A. K. (1981). Effect of a paired mixture of aldrin and formation on carbohydrate metabolism in a fish Heleropneustes fossilis. Pestic. Biochem. Physiol., 15(3): 257-261.

Soliman, F. M.; El-Elaimy, I. A. and Hamada, H. M. (1993). The effect of malathion on the histopathological changes in the liver of Gambusia affinis. J. Pest control and Environ. Sci. 5(1): 17-30. 
Verma, S. R.; Sarita, R.; Tonk, I. P. and Dalela. R. C. (1983). Pesticide induced dysfunction in carbohydrate metabolism in fresh water fishes. Environm. Res., 32(1) : 127-133.

Wester, P. W. (1988). Toxicological pathology in fish, an evaluation with two species and various environmental contaminants. Ph. D: Thesis. Nat. Inst. Pulb. Hith. Environ. Hyg. Bithoven. The Netherlands. 


\section{EFFECT OF THE INSECTICIDE "HOSTATHION" ON 117 THE LIVER OF CLARIAS GARIEPINUS}

Table 1: Determination of $96 \mathrm{~h} . \mathrm{LC}_{50}$ of the insecticide hostathion to the catfish (Clarias gariepinus)

\begin{tabular}{|c|c|}
\hline $\begin{array}{c}\text { Concentration } \\
(\mathrm{mg} / \mathrm{l})\end{array}$ & \% Mortality \\
\hline 1.0 & 10 \\
1.5 & 20 \\
2.0 & 30 \\
2.5 & 40 \\
3.0 & 50 \\
3.5 & 60 \\
4.0 & 70 \\
4.5 & 80 \\
5.0 & 90 \\
5.5 & 100 \\
\hline
\end{tabular}

Table (2). Change in $5^{\prime}$-nucleotidase and alkaline phosphatase activity in the liver of catfish after treatment with different concentrations of hostathion.

\begin{tabular}{|c|l|c|c|c|c|}
\hline \multirow{2}{*}{ Conc. } & \multirow{2}{*}{ Exposure time } & \multicolumn{2}{|c|}{$5^{\prime}$-nucleotidase } & \multicolumn{2}{c|}{ Alkaline phosphatase } \\
\cline { 3 - 6 } & & Mean $\pm \mathrm{SD}$ & $\%$ inhibition & Mean \pm SD & $\%$ inlribition \\
\hline \multirow{5}{*}{$\mathrm{LC}_{50}$} & 0 (control) & $2.250 \pm 0.04$ & 0 & $38.85 \pm 2.25$ & 0 \\
& 6 hrs. & $0.705 \pm 0.01^{* *}$ & -68.67 & $28.05 \pm 1.18$ & -27.79 \\
& 12 & $0.610 \pm 0.05^{* *}$ & -72.88 & $21.08 \pm 2.01^{*}$ & -45.74 \\
& 24 & $0.507 \pm 0.06^{* *}$ & -77.47 & $18.75 \pm 0.50^{*}$ & -51.37 \\
\hline \multirow{3}{*}{$1 / 2 \mathrm{LC}_{50}$} & 2 days & $0.618 \pm 0.04^{* *}$ & -72.53 & $12.85 \pm 0.78^{* *}$ & -66.92 \\
& 3 & $0.584 \pm 0.03^{* *}$ & -74.04 & $11.84 \pm 0.81^{* *}$ & -69.45 \\
& 4 & $0.487 \pm 0.02^{* *}$ & -78.36 & $10.91 \pm 0.080^{* *}$ & -71.91 \\
\hline \multirow{3}{*}{$1 / 4 \mathrm{LC}_{50}$} & 5 days & $0.408 \pm 0.05^{* *}$ & -81.87 & $13.28 \pm 1.09^{* *}$ & -65.80 \\
& 10 & $0.494 \pm 0.07^{* *}$ & -78.04 & $11.05 \pm 1.07^{* *}$ & -71.54 \\
& 15 & $0.568 \pm 0.08^{* *}$ & -74.76 & $10.21 \pm 1.03^{* *}$ & -74.71 \\
\hline
\end{tabular}

- Activity expressed as $\mu \mathrm{mol} / \mathrm{Pi} / \mathrm{min} / \mathrm{g}$. fresh tissue in $5^{\prime}$ nucleotidase and as kind and king unit/g. fresh tissue in alkaline phosphatase.

$\left.{ }^{*}\right)$. Significant at $\mathrm{p}<0.05,\left({ }^{*}\right)$ significant at $\mathrm{p}>0.01$ 
Fig. (1): Lethal-mortality curve of hostathion on the catfish

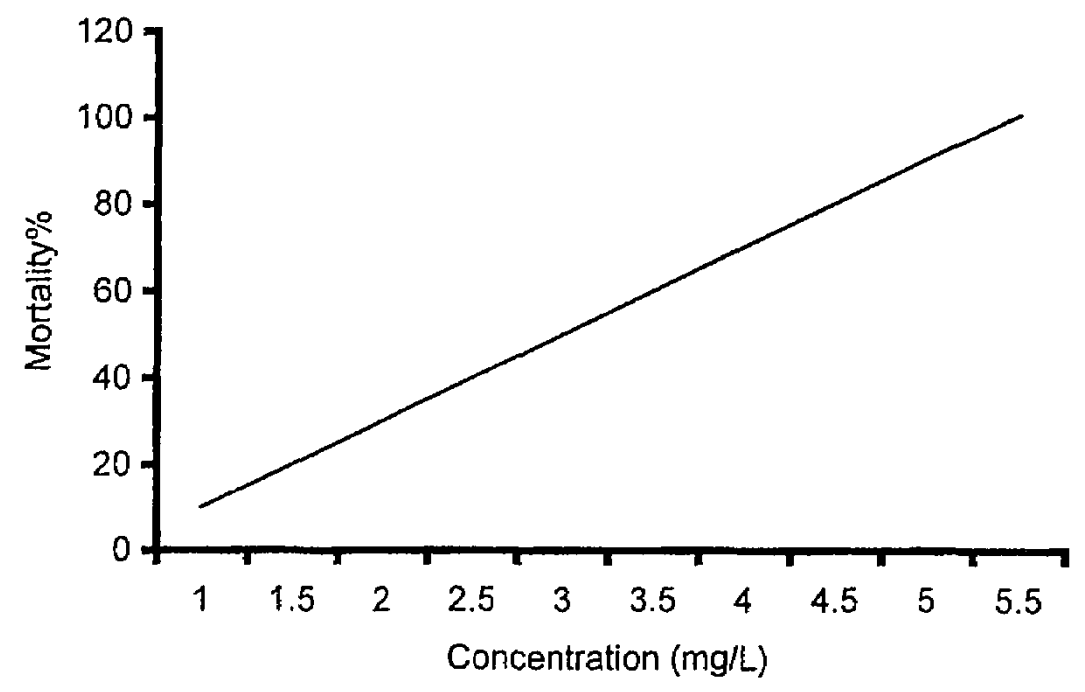




\section{EFFECT OF THE INSECTICIDE "HOSTATHION" ON 119 THE LIVER OF CLARIAS GARIEPINUS}

\section{List of Figures}

Fig. 2. Section in the liver of a control fish, $\mathrm{S}$ : sinusoidal lumen, $\mathrm{H}$ : hepatocytes, X320.

Fig. 3. Section in the liver of a fish treated with $\mathrm{LC}_{50}$ of hostathion and examined after 6 hours showing a congested vein (V) and inflammatory leucocytic infiltration (L) X320.

Fig. 4. Section in the liver of a fish after 12 hours of $\mathrm{LC}_{50}$ treatment showing degenerated hepatocytes with pyknotic nuclei $(P)$ and the sinusoidal lumen are filled with blood cells, X320.

Fig. 5. Section in the liver of a fish after 24 hours of $\mathrm{LC}_{50}$ treatment showing hepatocytes with marked cytoplasmic vacuolization and dilated and congested vein (V), X320.

Fig. 6. Section in the liver of a fish 2 days post-treatment with $1 / 2 L . C_{50}$ of hostathion showing necrotic area $(N)$ with degenerated hepatocytes, X320.

Fig. 7. Section in the liver of a fish 3 days post-treatment with $1 / 2 \mathrm{LC}_{50}$ of hostathion showing a large congested vein (V), X320.

Fig. 8. Section in the liver of a fish 4 days post-treatment with $1 / 2 \mathrm{~L}, \mathrm{C}_{50}$ of hostathion showing eytoplasmic vacuolization (CV), X320.

Fig. 9. Section in the liver of a fish treated with $1 / 4 \mathrm{LC} \mathrm{C}_{50}$ of hostathion and examined after 10 days showing inflammatory leucocytic infiltrations (L) and congested vein (V) X320.

Fig. 10. Section in the liver of a fish treated with $1 / 4 \mathrm{LC}_{50}$ for 15 days showing hepatocytes with nuclci suffereing from karyolysis(arrows), X320.

Fig. 11. Section in the liver of a treated fish showing hepatic cells with cytoplasmic vacuolization and binucleated liver cells (arrows), X320.

Fig. 12. Sections in the liver stained with PAS technique for demonstration of glycogen. a: control fish; b: 6hours after exposure to $\mathrm{LC}_{50}$ of hostathion; c: 24 hours after exposure to $\mathrm{LC}_{50}$ of hostathion; $\mathrm{d}: 2$ days after exposure to $1 / 2 \mathrm{LC}_{50}$ of hostathion; e: 4 days after exposure to $1 / 2 \mathrm{LC}_{50}$ of hostathion; f: 10 days after exposure to $1 / 4 \mathrm{LC}_{50}$ of hostathion.

Fig. 13. Sections in the livers stained with mercury bromophenol blue for total proteins. a: control fish; b: 6 hours after exposure to $\mathrm{LC}_{50}$ of hostathion; c: 24 hours after exposure to $\mathrm{LC}_{50}$ of hostathion; d: 2 days after exposure to $1 / 2 \mathrm{LC}_{50}$ of hostathion; e: 4 days after exposure to $1 / 2 \mathrm{LC}_{50}$ of hostathion, $\mathrm{f}$ : 15 days after exposure to $1 / 4 \mathrm{LC}_{50}$ of hostathion. 


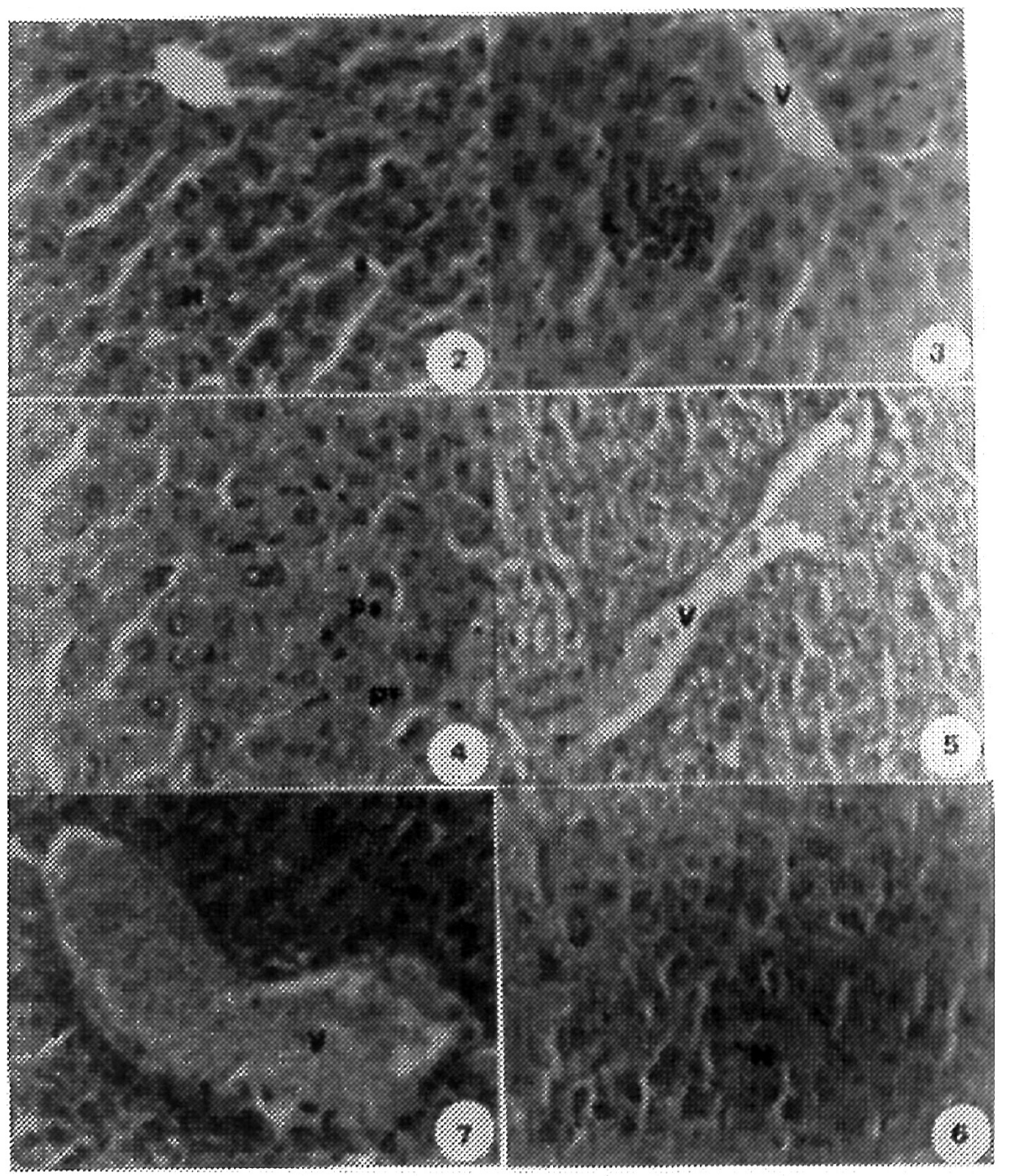




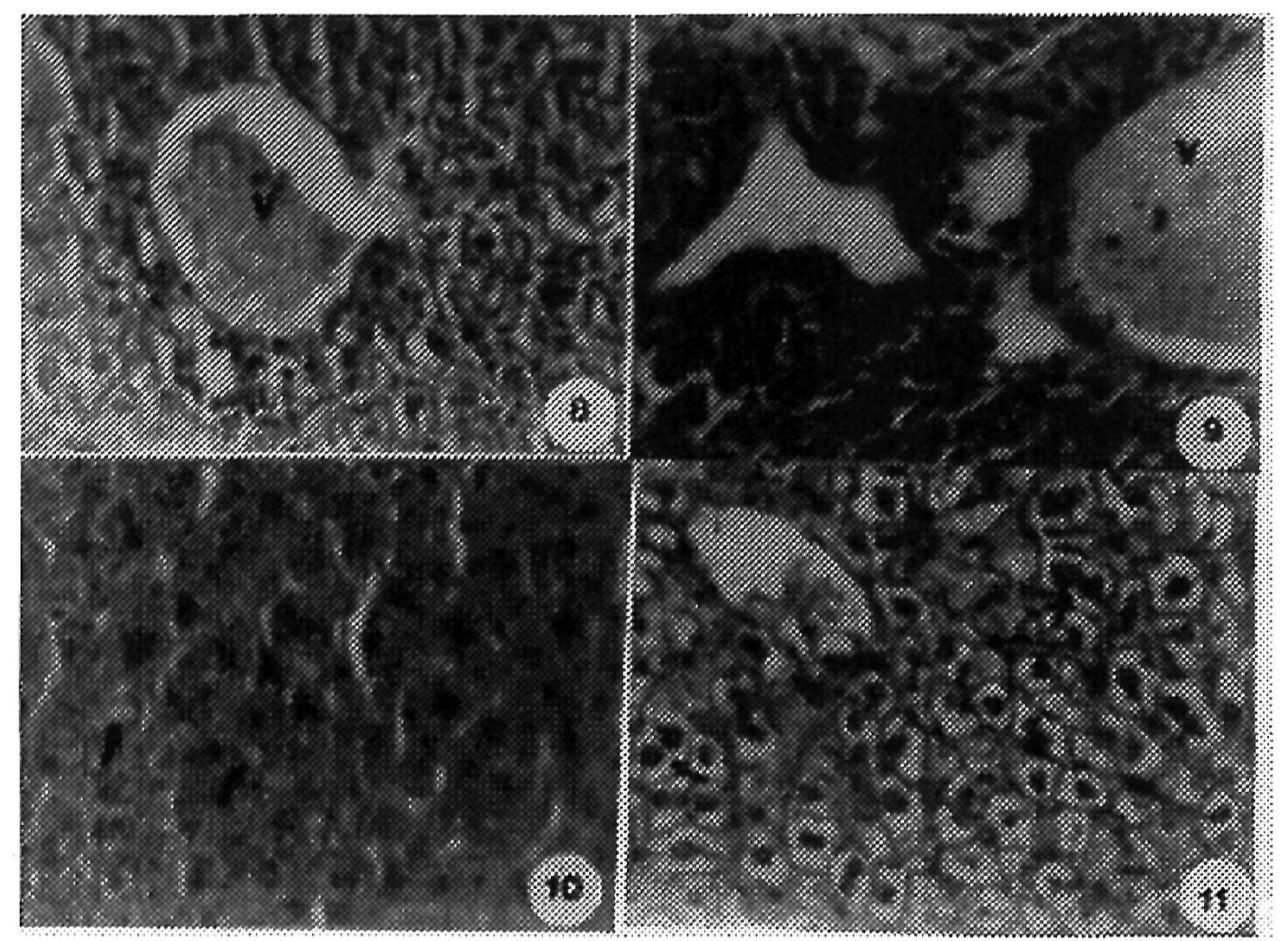




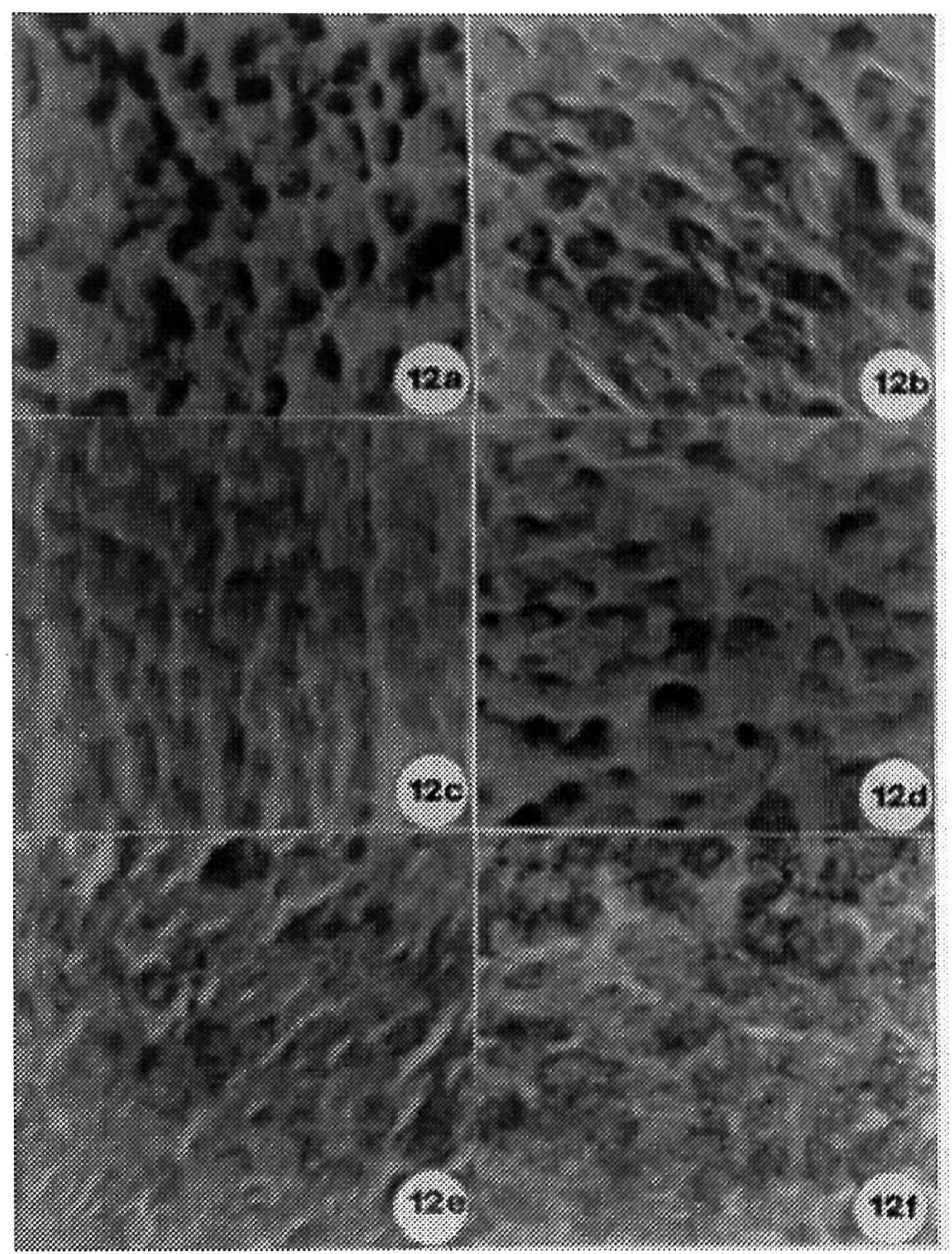




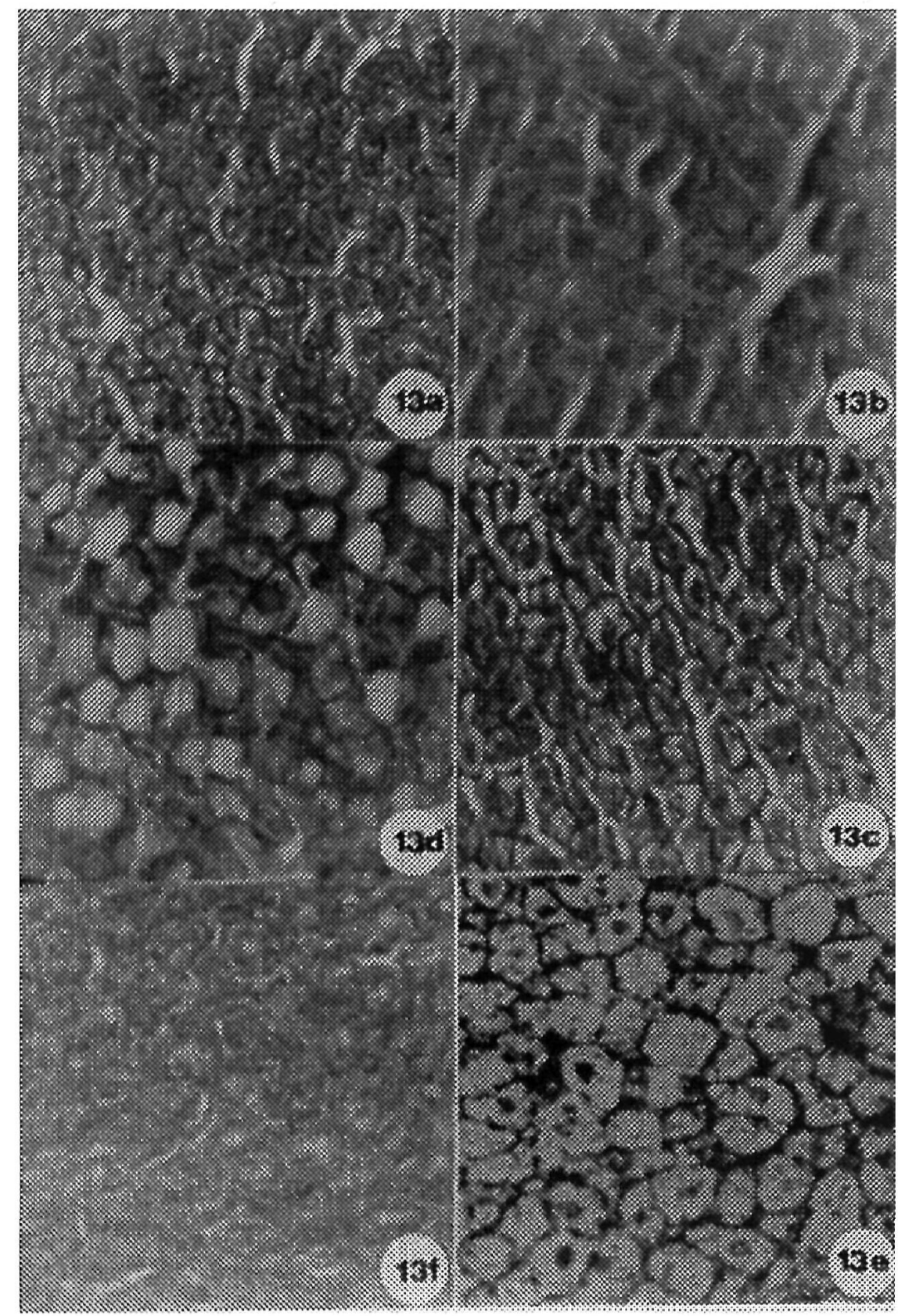

